\title{
SH19 - Aplicación de tecnologías de información y comunicación en educación superior: una alternativa para la difusión de investigación
}

\author{
Guisela López \\ Instituto Universitario de la Mujer \\ Universidad de San Carlos de Guatemala
}

\section{Resumen}

\begin{abstract}
$\mathrm{L}$ as Tecnologías de Información y Comunicación (TIC) se han considerado como un recurso que facilita el acceso a la información no obstante es necesario tomar en cuenta que su aplicación con lleva una serie de requerimientos que complejizan su incorporación. Pensando en las posibilidades que estos recursos tecnológicos ofrecen para ampliar la cobertura de difusión de resultados de las investigaciones producidas en la academia se desarrolló el presente estudio orientado a explorar los avances, limitaciones y retos que la aplicación de TIC ha tenido en la Universidad de San Carlos de Guatemala (USAC). Para desarrollar la investigación se empleó un método mixto, dirigido a obtener datos cuantitativos que permitieran diferenciar avances en las distintas unidades académicas, al mismo tiempo que analisizar las limitaciones y avances obtenidos. Como resultado del estudio se identificó que los recursos más utilizados en la difusión de los nuevos conocimientos producidos han sido: La página web, revistas electrónicas, bibliotecas y repositorios virtuales, así como las videoconferencias y los blogs. Se identificó así mismo la existencia de diferentes posiciones en torno a las TIC, ya que mientras algunas opiniones se centran en sus beneficios para democratizar la educación superior otras denuncian las brechas: Digitales, culturales, generacionales y de género que limitan su avance. En conclusión las TIC en la USAC no solo constituyen un tema complejo por lo que su desarrollo ha sido totalmente asimétrico, pues mientras algunos institutos cuentan con varios recursos tecnológicos otros apenas están iniciando con su primera aplicación.
\end{abstract}

Palabras clave: Tecnología, brechas digitales, investigación, educación superior y publicaciones electrónicas.

\begin{abstract}
$\mathrm{T}$ he Information and Communication Technologies (ICT) have been considered as a resource that provides access to information however it is necessary to note that your application has a series of requirements that complicate their incorporation. Thinking about the possibilities that these technological resources offer to extend coverage to disseminate research results produced at the academy. This study aimed to explore the progress, constraints and challenges that the application of ICT has had on the University Of San Carlos Of Guatemala (USAC). To develop a mixed method research aimed at obtaining quantitative data allowing to differentiate progress in the various academic units, while analyze limitations and advances obtained was used. As a result of the study it was identified that the most used in the dissemination of new knowledge resources have been produced: The web page, electronic journals, virtual libraries and repositories, as well as video conferencing and blogs. The existence of different positions around ICT identified himself, because while some opinions focus on its benefits to democratize higher education denounce other gaps: Digital, cultural, generational and gender that limit their advancement. In conclusion ICT in USAC not only constitute a complex issue so that its development has been completely asymmetric, while some schools have several other technological resources are just starting with your first application.
\end{abstract}

Keywords: Technology, digital divides, research, higher education and electronic publications. 